\title{
Investigation of origination and development of the surface deformation relief of crystalline materials by laser radiation
}

\author{
E.E.Badiyan, A.G.Tonkopryad, O.V.Shekhovtsov, \\ R.V.Shurinov, T.R.Zetova, K.S.Kazachkova \\ V. Karazin Kharkiv National University, \\ 4 Svobody Sq., 61022 Kharkiv, Ukraine
}

Received February 23, 2015

In the paper we present the results of the experimental studies of structure of the
deformation relief in the form of steps at the exit site of dislocations on polished surface
f polycrystalline specimen of aluminum during plastic deformation. It is shown that,
despite quasiperiodicity of such structure which is characterized by different values of the
grating period and the curved slip lines forming the grate, it leads to diffraction of the
aser radiation on it. The analysis of the diffraction patterns obtained in situ during
deformation allows us to trace the evolution of the deformation structures. It is experi-
mentally shown that the origination of the dislocation slip in the early stages of plastic
deformation can be detected and the direction of slip and change of this direction during
plastic deformation can be determined by using the diffraction patterns. The minimal
distance between the slip lines which characterize intensive development of the dislocation
lip can be detected by the diffraction patterns. Thus the intensity of plastic deformation
at all stages can be studied.

Keywords: plastic deformation, dislocation slip, quasiperiodic surface deformation relief, diffraction of laser radiation.

Приведены результаты экспериментальных исследований структуры деформационного рельефа в виде ступенек в месте выхода дислокаций на полированной поверхности поликристаллического образца алюминия в процессе его деформирования. Показано, что, несмотря на квазипериодичность этой структуры, которая характеризуется разными значениями периода дифракционной решетки и искривленными линиями скольжения, составляющими эту решетку, она приводит к дифракции на ней лазерного излучения. Анализ дифракционных картин, полученных in situ в процессе деформирования, позволяет проследить за эволюцией деформационной структуры. Экспериментально показано, что с помощью дифракционных картин можно обнаружить возникновение дислокационного скольжения на ранних стадиях пластической деформации, определить направление скольжения и изменение этого направления в процессе деформирования. Дифракционная картина позволяет определять минимальное расстояние между линиями скольжения, характеризующее интенсивность развития дислокационного скольжения. Таким образом, можно проследить за интенсивностью развития пластической деформации на всех ее стадиях.

Дослідження виникнення та розвитку деформаційного рельсфу на поверхні кристалічних матеріалів з використанням лазерного випромінювання. Є.Ю.Бадіян, А.Г.Тонкопряд, О.В.Шеховцов, Р.В.Шурінов, Т.Р.Зєтова, К.С.Казачкова.

Наведено результати експериментальних досліджень структури деформаційного рельєфу у вигляді сходинок у місці виходу дислокацій на полірованій поверхні полікристалічного зразка алюмінію в процесі його деформування. Показано, що, незва- 
жаючи на квазіперіодичність цієї структури, яка характеризується різними значеннями періоду дифракційної решітки та викривленими лініями ковзання, що складають цю решітку, вона приводить до дифракції на ній лазерного випромінювання. Аналіз дифракційних картин, одержаних in situ у процесі деформування, дозволяє простежити за еволюцією деформаційної структури. Експериментально показано, що за допомогою дифракційних картин можна виявити виникнення дислокаційного ковзання на ранніх стадіях пластичної деформації, визначити напрям ковзання і змінення цього напрямку у процесі деформування. Дифракційна картина дозволяє визначати мінімальну відстань між лініями ковзання, що характеризує інтенсивність розвитку дислокаційного ковзання. Таким чином, можна простежити за інтенсивністю розвитку пластичної деформації на всіх її стадіях.

\section{Introduction}

It is well known that plastic deformation of the crystalline specimens is carried out by dislocation slip. Thus the deformation relief occurs in the form of traces of slip (slip lines) that have shape of steps on the polished specimen surface as a result of the emergence of dislocations. The character of the deformation relief is changing during plastic deformation. Analysis of information on the character of the deformation relief and its changes during deformation gives an indication of the physical processes which accompany and determine the plastic deformation of crystalline materials.

Typically the surface structure of plastically deformed specimens is studied by means of light or electron microscopy. In recent papers tunneling microscopy [1], photoemission techniques [2] are used. Recently the possibility of scattering of white light and laser radiation on quasiperiodic structures, which appear on the crystalline specimen surface after chemical etching was shown $[3,4]$. For example, micrograph of such quasiperiodic structure which originates on the surface of one of the grains of an $\mathrm{Al}$ polycrystalline specimen after chemical etching is given in Fig. 1a. This quasipe-

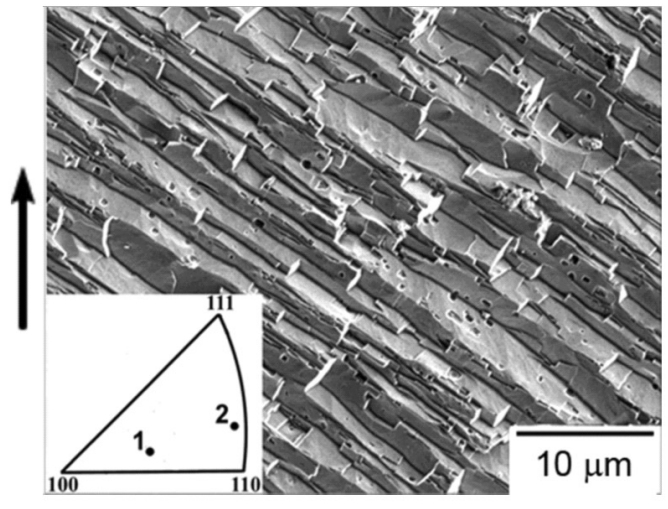

a) riodic structure is formed by etch grooves, the direction of which is determined by crystallographic surface orientation. The crystallographic orientation of the grain relative to the normal to the grain surface and the direction shown by arrow is presented in the basically crystallographic triangle. Photomicrograph was obtained using scanning electron microscope Jeol JSM-840. Intensity distribution of the laser radiation $(\lambda=633 \mathrm{~nm})$ scattered by this quasi-periodic structure is shown in Fig. $1 \mathrm{~b}$, where the value of radius-vector $\mathbf{R}$ in any direction is proportional to the intensity of laser light scattered in this direction. Such intensity distribution was observed on the screen which is parallel to the sample surface and perpendicular to the laser beam (Fig. 2). Figures 1a, b show that scattering indicatrix is fully determined by the character of the quasi-periodic structures. The maximum scattering $(R=$ $R_{\max }$ ) is observed in the direction which is perpendicular to the grooves of the quasi-periodic structure with a minimal period.

In view of the foregoing, it can be assumed that the similar effect of scattering may occur as a result of interaction of laser radiation with the deformation relief which originates on the specimen surface during plastic deformation.

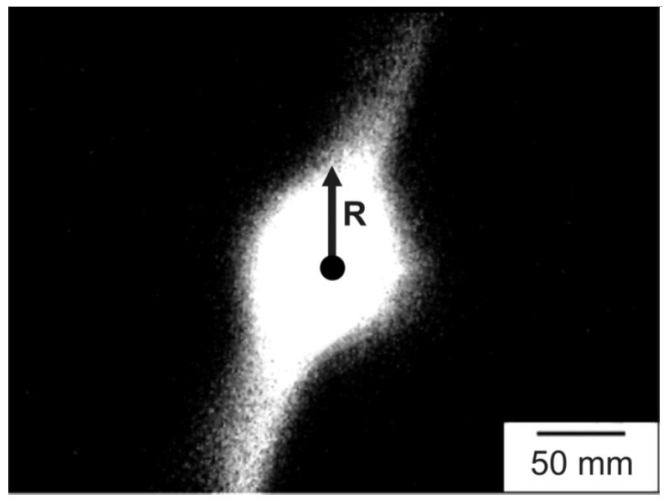

b)

Fig. 1. Quasiperiodic surface structure of one of the grains of Al polycrystalline specimen surface after chemical etching (a), and scattering pattern of laser radiation on this structure (b). 


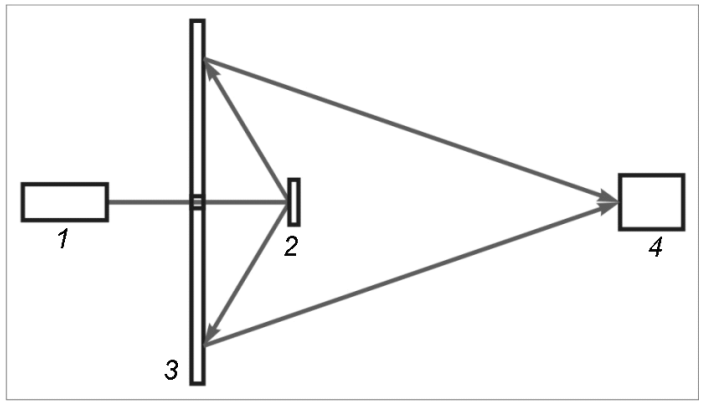

Fig. 2. Recording scheme of scattering pattern of laser radiation by the specimen surface: 1 - laser; 2 - specimen; 3 - screen with a hole for observing the radiation scattered by the specimen surface; 4 - computer-connected digital camera.

\section{Experimental}

Scheme for method to verify this assumption is shown in Fig. 2. Specimen (2) is fixed in the capture of the deforming device. A beam of $\mathrm{He}-\mathrm{Ne}$ laser (1) is directed perpendicularly to the specimen surface through the aperture in the screen (3). The laser beam scattered by the specimen surface is recorded in the form of scattering patterns on the screen (3). The scattering patterns were recorded using computer-connected Web-camera (Creative PC CAM 300) with a period of 0.02 seconds. Thus, it was possible to follow the scattering indicatrix change which characterizes origination and development of the surface deformation relief in situ during plastic deformation.

Polycrystalline aluminum specimens were used as the study objects. To reveal the grain boundaries, the Keller etchant [5] was used. Then, one surface of the specimen was ground and polished to register the deformation relief arising during plastic deformation. The other side of the specimen remained intact to be selected on the specimen surface (with identified grain boundaries) area for investigation. The specimens were strained under active uniaxial tension conditions at the constant straining rate $\dot{\varepsilon} \approx 10^{-5} \mathrm{~s}^{-1}$.

\section{Results and discussions}

Photographs of the Al specimen surface with grain boundary after chemical etching before deformation and after deformation by $15 \%$ are shown in Fig. 3. Regions in the grain boundary and on the surface of each of the grain away from the boundary have been selected as the study areas. These study areas are shown by dots in Fig. 3b.

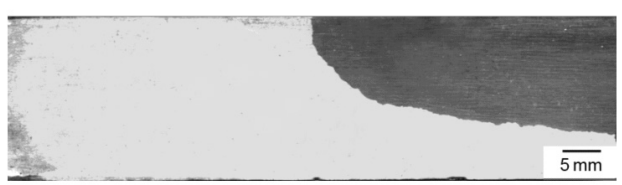

a)

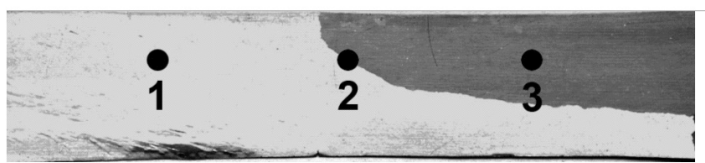

b)

Fig. 3. Photograph of Al bicrystal surface with grain boundary after chemical etching before deformation (a) and after deformation by $15 \%$ (b).

Recording of the scattering patterns of laser radiation on the deformation relief and microscopic studies of the structure of this relief were carried out in these areas but on the opposite (polished) surface of the specimen.

Figure 4a shows the microphotographs of the typical structure of the polished specimen surface and the corresponding scattering patterns of laser radiation before deformation. The scattering indicatrix indicates the isotropic scattering of the laser beam by the polished specimen surface. The photomicrographs of the deformation relief which was formed in the different regions of the polished specimen surface after deformation by $15 \%$ and scattering patterns of laser radiation on this structure are shown in Fig. $4 \mathrm{~b}, \mathrm{c}, \mathrm{d}$.

Specific quasiperiodic structure in the form of slip lines was detected in each of the three studied areas of the deformed specimen surface. The character and orientation of the slip lines are determined by crystallographic orientation of this area. The scattering indicatrix indicates the anisotropic scattering of the laser radiation on this quasiperiodic structure. Only one direction of maximum scattering which is perpendicular to the slip lines was registered on the surface areas where only one slip system was identified. Two directions of maximum scattering each of which is perpendicular to the certain slip system were registered on the grain boundary region of the specimen surface where the two slip systems are identified. Thus, the character of the laser light scattering by the deformation relief reflects its structure.

As will be shown below, the use of laser radiation for investigation of regularities of 

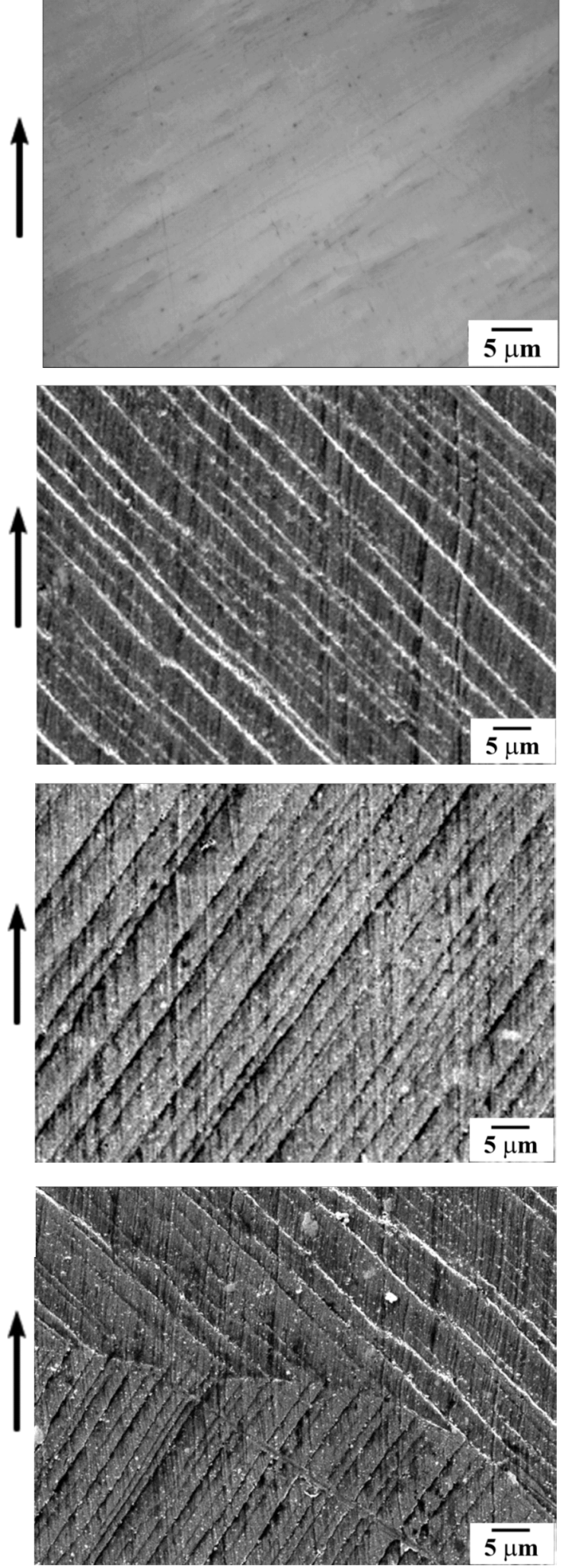

a)

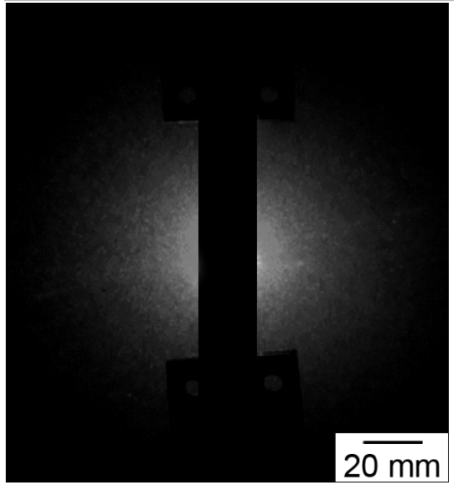

Grain 1

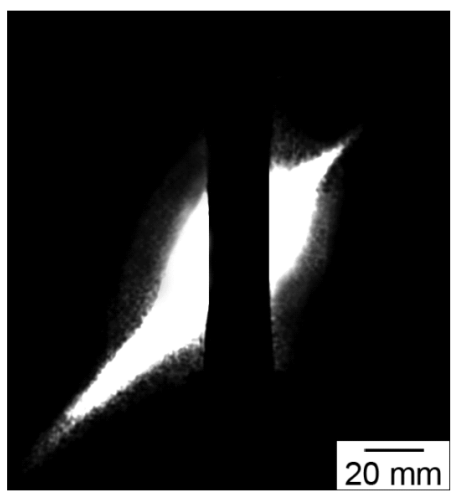

b)

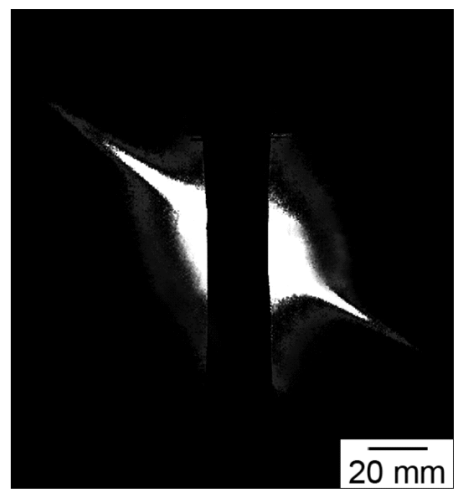

c)

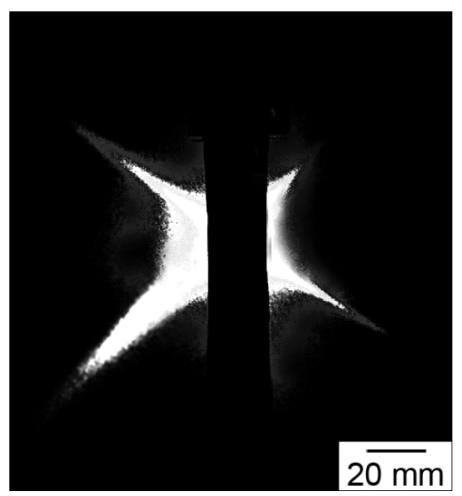

Fig. 4. Microphotographs of typical structure of the polished Al bicrystal surface and the corresponding scattering patterns of laser radiation before deformation (a) and after deformation by $15 \%(b, c, d)$. Areas of study are shown by dots in Fig. 3b. Direction of tensile of the specimen is shown by arrow. 


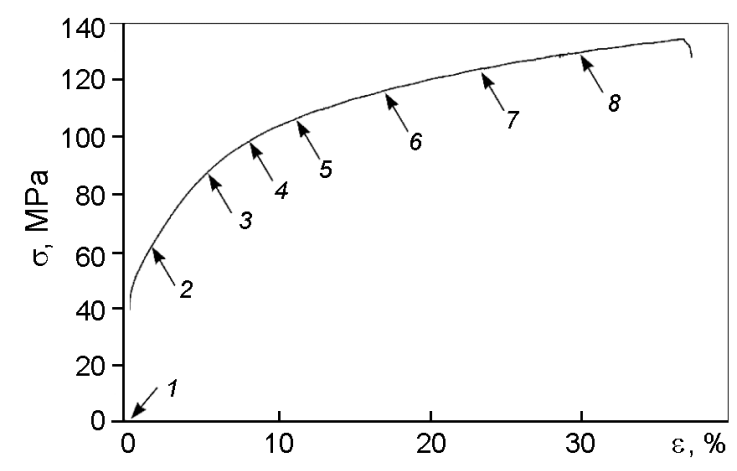

Fig. 5. Deformation curve of the Al polycrystalline specimen.

origination and development of the deformation relief is quite effective and informative.

For example, it is shown in experiment that this technique allows to detect the origination of the slip at the early stages of plastic deformation when it is visually invisible. The scattering indicatrix allows with sufficiently high accuracy to detect the slip direction and change it during plastic deformation of the specimen, and the exact same appearance of the new slip systems. It allows estimating the contribution of the slip systems in the plastic deformation of the speci men as a whole. Laser radiation scattering by the deformation relief arising during deformation of crystalline materials

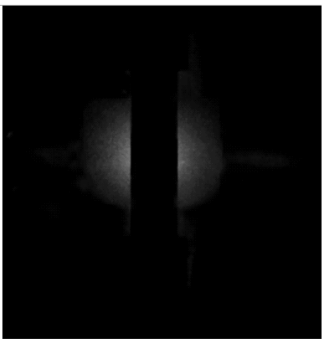

a)

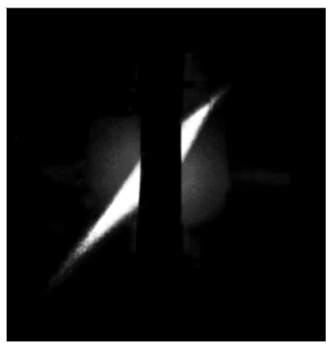

e)

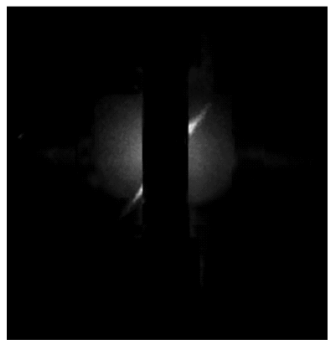

b)

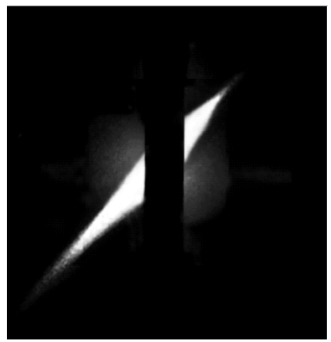

f)

can be used to determine the intensity of the dislocation slip which has density of the slip lines.

The results of the experimental investigation of laser radiation scattering by the surface of one of the grains of the Al polycrystalline specimen are shown below. The scattering patterns were recorded in situ during deformation of the specimen. The distance between the sample and the screen was $170 \mathrm{~mm}$. The study area on the surface was $\approx 2 \mathrm{~mm}^{2}$.

Figure 5 shows the deformation curve of the Al polycrystalline specimen. In Fig. 6 it is shown the fragments of movie of the scattering patterns of laser radiation on the deformation relief which originates on the surface of one of the grains during the specimen deformation. On the deformation curve (Fig. 5) arrows indicate the values of the specimen relative deformation corresponding to these scattering patterns.

The scattering patterns in Fig. 6 show that only one slip system in the investigated grain is active until failure of the specimen and the slip direction does not change during the plastic deformation. The average (or minimum) distance between the slip lines may serve to characterize the intensity of the slip. It is well known that the deformation relief occurs in the form of steps on the crystalline specimen surface in place where the emergence of dislocations [6]. The

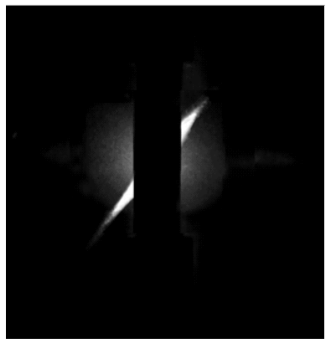

c)

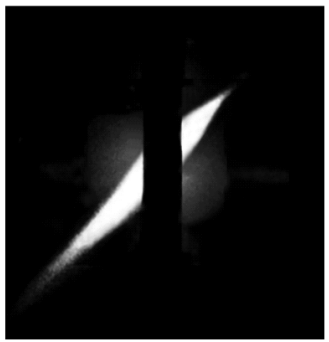

g)

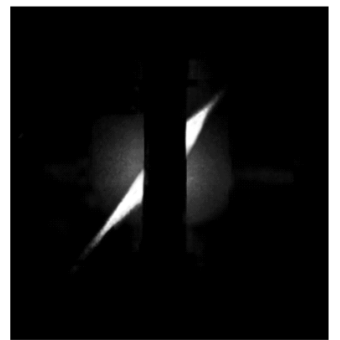

d)

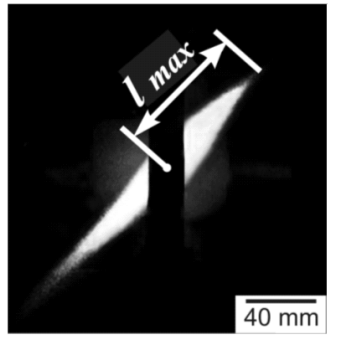

h)

Fig. 6. Scattering patterns of laser beam on the deformation relief which occurs on the polished specimen surface during plastic deformation: $\varepsilon=0 \%$ (a); $\varepsilon=6 \%$ (b); $\varepsilon=10 \%$ (c); $\varepsilon=13 \%$ (d); $\varepsilon=18 \%(\mathrm{e}) ; \varepsilon=24 \%$ (f); $\varepsilon=31 \%(\mathrm{~g}) ; \varepsilon=37 \%$ (h). 
process of formation of the slip lines is carried out at different scale levels [7]. At the initial stages of plastic deformation the steps are formed in the nanometer scale, and this formation has stochastic nature. Formation of the deformation quasiperiodic structure of micron scale comes from this nanometer scale level [8]. This structure can lead to diffraction of the laser radiation on it as will be shown below. The quasiperiodic structure on the specimen surface which consists of the slip traces (lines) can serve diffraction grating. The diffraction equation for normal incidence of light on the diffraction grating can be written as $d \sin \varphi_{m}$ $=m \lambda$, where $\lambda$ is wavelength, $d$ is the grating period, $\varphi_{m}$ is angle of diffraction of $m$ order $(m=0, \pm 1, \pm 2 \ldots)$.

For the diffraction maximum of the first order there is $\lambda / d<1$ or $d>\lambda$. For recorder of the diffraction pattern it is necessary that $d>0.633 \mu \mathrm{m}$ when using laser radiation with wavelength of $0.633 \mu \mathrm{m}$. Periodic structure of the deformation relief on the specimen surface which is represented in the micrographs (Fig. 4) corresponds to this condition. The value $d$ within the investigated area of the specimen surface varies from 1 to $25 \mu \mathrm{m}$. The quasiperiodic structure which is shown in Fig. 4 is characterized by two features: non-permanent value of the period $d$ and the curvature of the slip lines that form diffraction grating. The first one should lead to blurring of the diffraction pattern in the direction of diffraction. The second one has the same effect in the direction perpendicular to the diffraction direction. The both effects are observed experimentally (Fig. 6). The experimental results show that the parameters of the quasiperiodic structure on the specimen surface can be determined by shape and parameters of the diffraction pattern in situ during the specimen deformation. In particular, the value of $l_{\max }$ (Fig. 6) allows determining the minimal distance between the slip lines which characterizes the intensity of development of the plastic deformation. Fig. 7 shows dependence of the minimal distance between the slip lines $d_{m i n}$ and the quantity $1 / d_{\text {min }}$ on the specimen relative deformation for one of the investigated grains of the $\mathrm{Al}$ polycrystalline specimen.

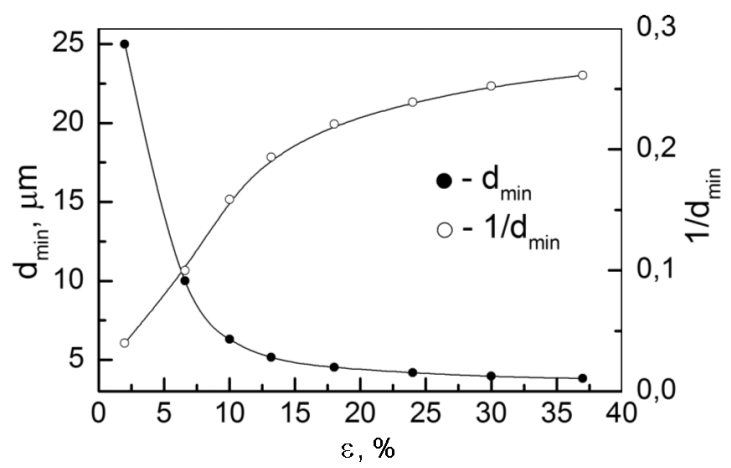

Fig. 7. Dependence of the minimal distance between slip lines $d_{m i n}$ and the quantity $1 / d_{\min }$ on the specimen relative deformation $\varepsilon$.

\section{Conclusions}

It is shown in the experiment that quasiperiodic structure in the form of steps at the exit site of dislocations which occurs on the polished specimen surface after deformation can lead to diffraction of laser radiation on it. The diffraction patterns obtained from the specimen surface in situ during plastic deformation provide information about the regularities of origination and development of the dislocation slip. For example, such studies allow determining the slip direction and its changes during the deformation, the origination and development of the secondary slip, the relative contribution of each of them in the plastic deformation of the investigated specimen area. The minimal distance between the slip lines which characterizes the intensity of the dislocation slip can be determined from the diffraction pattern.

\section{References}

1. V.I.Vettegren, V.N.Svetlov, Fizika Tverdogo Tela, 46, 1996 (2004).

2. M.Cai, L.E.Levine, S.C.Langford, J.T.Dickinson, Mater. Sci. Engin., A400-401, 476 (2005).

3. E.E.Badiyan, A.G.Tonkopryad, O.V.Shehovtsov, R.V.Shurinov, Inorgan. Mater., 15, 1663 (2011).

4. Patent Ukraine 89743 .

5. M.Beckert, Ch.Klemm, Spravochnik po Metallograficheskomu Travleniju, Metallurgia, Moscow (1980) [in Russian].

6. G.A.Malyigin, Fizika Tverdogo Tela, 43, 248 (2001).

7. D.V.Lyichagin, V.A.Starenchenko, Yu.V.Soloveva, Fizicheskaya Mezomehanika, 8, 67 (2005). 